\title{
THYROGLOBULIN AS A TUMOR MARKER IN DIFFERENTIATED THYROID CANCER - CLINICAL CONSIDERATIONS
}

\author{
Marin Prpić ${ }^{1,2}$, Maja Franceschi ${ }^{1,2,3}$, Matija Romić ${ }^{1}$,Tomislav Jukić ${ }^{1,2,3}$ and Zvonko Kusic ${ }^{4,5}$ \\ ${ }^{1}$ Department of Oncology and Nuclear Medicine, Sestre milosrdnice University Hospital Centre, Zagreb, Croatia; \\ ${ }^{2}$ School of Medicine, University of Zagreb, Zagreb, Croatia; \\ ${ }^{3}$ Faculty of Medicine, Josip Juraj Strossmayer University of Osijek, Osijek, Croatia; \\ ${ }^{4}$ Croatian Academy of Sciences and Arts, Zagreb, Croatia; \\ ${ }^{5}$ Aviva Polyclinic, Zagreb, Croatia
}

\begin{abstract}
SUMMARY - Initial treatment of the majority of patients with differentiated thyroid cancer (DTC) includes total thyroidectomy. Postoperative ablation therapy with radioactive iodine (I-131) is indicated in all high-risk patients, however, there is disagreement regarding its use in low- and intermediate-risk patients. Over the last few decades, thyroglobulin $(\mathrm{Tg})$ has been established as the primary biochemical tumor marker for patients with DTC. Thyroglobulin can be measured during thyroid hormone therapy or after thyroid-stimulating hormone (TSH) stimulation, through thyroid hormone withdrawal or the use of human recombinant TSH. In many studies, the cut-off value for adequate $\mathrm{Tg}$ stimulation is a TSH value $\geq 30 \mathrm{mIU} / \mathrm{L}$. However, there is an emerging body of evidence suggesting that this long-established standard should be re-evaluated, bringing this threshold into question. Recently, a risk stratification system of response to initial therapy (with four categories) has been introduced and $\mathrm{Tg}$ measurement is one of the main components. The relationship between the $\mathrm{Tg} / \mathrm{TSH}$ ratio and the outcome of radioiodine ablation has also been studied, as well as clinical significance of serum thyroglobulin doubling-time. The postoperative serum $\mathrm{Tg}$ value is an important prognostic factor that is used to guide clinical management, and it is the most valuable tool in long term follow-up of patients with DTC.
\end{abstract}

Key words: Thyroglobulin; Thyroid neoplasms; Thyroidectomy; Iodine radioisotopes; Biomarkers, tumor; Thyroid hormones; Croatia

\section{Introduction}

Thyroid cancer is the most common type of endocrine malignancy ${ }^{1}$. About $90 \%$ of thyroid neoplasms are differentiated thyroid cancers (DTC) with low malignant potential and a very good prognosis ${ }^{2}$. Over the last few decades, the incidence of thyroid cancer has considerably increased. The age-standardized incidence rate of thyroid cancer has increased in Croatia

Correspondence to: Maja Franceschi, $M D, P h D$, Department of Oncology and Nuclear Medicine, Sestre milosrdnice University Hospital Centre, Vinogradska c. 29, HR-10000 Zagreb, Croatia

E-mail: maja.franceschi@gmail.com

Received May 17, 2016, accepted June 27, 2017
22.1 times in women and 5.6 times in men in the period from 1968 to 2014, with a decrease in mortality ${ }^{3}$. A similar trend has been observed around the world. In the United States, the yearly incidence has almost tripled from 4.9 in 1975 to 14.3 per 100,000 in 2009, without associated increase in mortality ${ }^{4}$. This perceived increased incidence of DTC is mostly caused by more intensive imaging with neck ultrasonography (US) and the aggressive use of US guided fine needle aspiration biopsy (FNA), which has led to detection of disease in early stages ${ }^{5,6}$.

In the majority of patients with DTC, initial treatment consists of total thyroidectomy. However, lobectomy may be performed in patients with microcarci- 
noma without nodal metastases on imaging ${ }^{7,8}$. Postoperative ablation therapy with radioactive iodine (I-131) is indicated in all high-risk patients, however, there is disagreement regarding its indication and dosage in low- and intermediate-risk patients ${ }^{9-11}$. The introduction of L-levothyroxine substitution or suppression therapy is the next step in the treatment of these patients, which depends on balancing the degree of response to initial therapy and increasing the risk of adverse effects related to thyroid-stimulating hormone (TSH) suppression ${ }^{12}$. With this treatment approach, the majority of patients have an excellent prognosis with normal life expectancy ${ }^{13}$. However, in some patients, persistent disease is present after initial therapy, or disease recurrence is detected during follow-up.

Thyroglobulin $(\mathrm{Tg})$ is a glycoprotein with a molecular weight of approximately $660 \mathrm{kDa}$, which is synthesized by thyrocytes and released into the lumen of thyroid follicles ${ }^{14}$. Production of Tg is stimulated by TSH, intrathyroidal iodine deficiency or excess ${ }^{15}$, and the presence of thyroid-stimulating immunoglobulins. Thyroglobulin plays a crucial role in the synthesis of the peripheral thyroid hormones triiodothyronine (T3) and thyroxine (T4), containing tyrosine residues which are iodinated using tyrosine oxidase in monoiodotyrosine and diiodotyrosine forms (MIT and DIT), which then form T3 and T4. Over the last few decades, the role of $\mathrm{Tg}$ as the primary biochemical tumor marker in patients with DTC has been established. Serum Tg measurements, neck ultrasonography, and occasionally diagnostic I-131 whole body scintigraphy are used in the follow up of DTC patients ${ }^{16-18}$. Neck ultrasonography is a readily available, noninvasive, cost-effective method, which can guide diagnostic procedures with low complication rates ${ }^{19}$. Recently, some authors have proposed the combined use of the above mentioned modalities with computed tomography $(\mathrm{CT})$, magnetic resonance imaging (MRI), and positron emission tomography (PET) including [F18] FDG PET/CT when necessary ${ }^{11,20,21}$. Patients at low risk of disease recurrence may be followed up only by neck US and serum $\mathrm{Tg}$ measurement $\mathrm{t}^{22}$.

\section{Measurement of Thyroglobulin and Anti-Thyroglobulin Antibodies}

Thyroglobulin has been measured by three different classes of methodology. Radioimmunoassay (RIA used since the 1970s), immunometric assay (IMA) since the 1980s, and liquid chromatography-tandem mass spectrometry (LC-MS/MS), which was developed in 2008. Immunometric assays are more sensitive than RIA and have shorter incubation time, wider working range and a stable labeled antibody reagent ${ }^{23}$. The proposed functional sensitivity of current assays is $\leq 0.1 \mu \mathrm{g} / \mathrm{mL}^{24}$. Serum $\mathrm{Tg}$ should be measured by validated immunoassays calibrated against the Certified Reference Material (CRM 457, now described as BCR 457, European Commission, Institute for Reference Material and Method). Laboratories providing Tg measurements are required to participate in certified national or international programs of quality assurance. Ideally, follow-up of DTC patients with Tg and anti-thyroglobulin antibodies (TgAb) concentrations should be performed in the same laboratory using the same assay each time ${ }^{24}$.

Anti-thyroglobulin antibodies are $330 \mathrm{kd}$ molecules which are often undetectable using older techniques. The $\mathrm{TgAb}$ is polyclonal, belongs to the $\mathrm{IgG}$ class of antibodies, not restricted to a particular subclass, although IgG2 is the predominant class in DTC $^{25}$. Anti-thyroglobulin antibodies falsely lower serum $\mathrm{Tg}$ in immunometric assays and are present in approximately $25 \%$ of thyroid cancer patients and $10 \%$ of the general population ${ }^{26,27}$. They are the most serious problem that limits the clinical value of $\mathrm{Tg}$ determination. Anti-thyroglobulin antibodies should be measured in conjunction with serum $\mathrm{Tg}$ assay by the same method to increase accuracy. After total thyroidectomy and I-131 remnant ablation, TgAb usually disappear after 3 years in patients without persistent disease. Thyroglobulin antibody levels that decline over time are considered as a good prognostic sign, while rising levels, or a new appearance of $\mathrm{TgAb}$ increases the risk of persistent or recurrent disease $\mathrm{e}^{28-31}$.

\section{Preoperative Role of Thyroglobulin}

Many studies have evaluated preoperative serum $\mathrm{Tg}$ values as a possible predictor of malignancy in thyroid nodules. Currently, the American Thyroid Association does not recommend routine preoperative measurement of serum $\mathrm{Tg}$ and $\mathrm{TgAb}$ since there is no definite evidence that this impacts patient management or outcome. Meanwhile, the most recent EPIC study demonstrated a strong positive association be- 
tween thyroid cancer risk and blood levels of $\mathrm{Tg}$, but did not support the use of serum $\mathrm{Tg}$ level for screening and early detection of DTC ${ }^{11,32}$.

\section{Postoperative Measurement of Thyroglobulin}

The half-life of serum $\mathrm{Tg}$ is $1-3$ days, and the postoperative nadir is reached in almost all patients 3-4 weeks after operation ${ }^{33,34}$. After therapy with I-131, it takes several months for $\mathrm{Tg}$ to completely disappear from the circulation ${ }^{35}$. The measurement of $\mathrm{Tg}$ can be done during thyroid hormone therapy or after TSH stimulation, through thyroid hormone withdrawal or the use of human recombinant TSH (rhTSH) $)^{36-38}$. Reports have questioned the possibility of a shorter duration of thyroid hormone withdrawal prior to $\mathrm{Tg}$ measurement ${ }^{39}$. Recombinant human thyrotropin is approved in many countries for preparation of patients without distant metastases for radioiodine ablation. This exogenous method of elevating TSH levels may also be used in patients who are unable to achieve adequate TSH elevation following thyroid hormone withdrawal, or in patients with significant comorbidities ${ }^{40}$. The rhTSH stimulated $\mathrm{Tg}$ levels tend to be lower than those following thyroid hormone withdrawal ${ }^{11,41}$.

\section{Cut-offTSH Threshold of $30 \mathrm{mIU} / \mathrm{L}$}

In many studies, the cut-off value for adequate thyroglobulin stimulation is a TSH value $\geq 30 \mathrm{mIU} / \mathrm{L}^{11,42}$. This value has its diagnostic (elevation of $\mathrm{Tg}$ ) and therapeutic (increased I-131 uptake in tumors) implications $^{43}$. However, there is an emerging body of evidence suggesting that this long-established standard should be re-evaluated, thus bringing this threshold into question. Although the value of TSH of 30 $\mathrm{mIU} / \mathrm{L}$ has been generally used in stimulation for I-131 ablation, some authors postulate different values. For example, Vrachimis et al. published a report on patients who received ablation with $\mathrm{TSH}<30$, with the same ablation outcome ${ }^{44}$. On the other hand, some authors advocate the use of higher TSH values, suggesting them to be connected with better treatment outcome ${ }^{45,46}$. In our two previous studies, no differences were observed comparing TSH levels and the ablation outcome $\mathrm{e}^{47,48}$.

\section{Thyroglobulin and Radioiodine Ablation}

The postoperative serum $\mathrm{Tg}$ value is an important prognostic factor that can be used to guide clinical management, especially in guiding the decision-making process leading to radioiodine ablation treatment, as well as predict successful ablation of the thyroid remnant. Postoperative serum $\mathrm{Tg}$ values $>10 \mathrm{ng} / \mathrm{mL}$ increase the probability of persistent or recurrent disease, failing I-131 ablation, presence of distant metastases, and mortality, therefore prompting additional evaluation and treatment $\mathrm{t}^{49-52}$. It is very important to emphasize that $\mathrm{Tg}$ level is not the only criterion for successful ablation, and that patient risk group should also be carefully considered. In low-risk patients, suppressed or stimulated $\mathrm{Tg}<1 \mathrm{ng} / \mathrm{mL}$ confirms low recurrence risk $^{51,53}$. In intermediate-risk patients, the same $\mathrm{Tg}$ values do not completely rule out the presence of smallvolume I-131-avid metastatic disease. In high-risk patients, even postoperative $\mathrm{Tg}$ values $<1 \mathrm{ng} / \mathrm{mL}$ do not rule out RAI-avid disease and therefore do not influence the decision to proceed with I-131 ablation ${ }^{11}$.

In conclusion, there is no optimal cut-off for postoperative serum $\mathrm{Tg}$ values to help determine indication for I-131 ablation in the American Thyroid Association (ATA) guidelines ${ }^{11}$. However, some authors recommend omission of I-131 ablation in patients with low postoperative stimulated $(\leq 1 \mathrm{ng} / \mathrm{mL})$ and non-stimulated $\mathrm{Tg}$ levels $(0.2-0.3 \mathrm{ng} / \mathrm{mL})$ with negative $\mathrm{TgAb}^{54-56}$. A recent study by Mourão et al. concluded that patients with papillary thyroid carcinoma with low non-stimulated $\mathrm{Tg}$ levels $(\mathrm{Tg}<0.3 \mathrm{ng} / \mathrm{mL}$ ) and negative nodal status in the neck following thyroidectomy did not require postoperative I-131 treatment ${ }^{57}$. Thyroglobulin levels are especially important in patients from low- and intermediate-risk groups, where the selection of patients for adjuvant therapy can be made based on $\mathrm{Tg}$ values. Additionally, some studies addressed the correlation of postoperative serum $\mathrm{Tg}$ values with success of remnant ablation; higher rates of ablation failure were observed with $\mathrm{Tg}$ values $>5-6 \mathrm{ng} / \mathrm{mL}$ regardless of I-131 activity ${ }^{58,59}$.

\section{Thyroglobulin/Thyrotropin Ratio as a Predictive Factor for Radioiodine Ablation Outcome}

In recent literature, the relationship between thyroglobulin/thyrotropin ratio and the outcome of radioiodine ablation has been extensively studied. For exam- 
ple, Trevizam et al. bring into question the hypothesis that thyroglobulin levels and the thyroglobulin/thyrotropin ratio may accurately predict the success of radioiodine ablation therapy in patients with DTC. The $\mathrm{Tg}$ and $\mathrm{Tg} / \mathrm{TSH}$ ratio cut-off values that predicted success of I-131 therapy were $4.41 \mathrm{ng} / \mathrm{mL}$ and 0.093 , respectively. After multivariate analysis, only serum $\mathrm{Tg}$ emerged as an independent factor predicting ablation outcomes $^{60}$. Further evidence for $\mathrm{Tg} / \mathrm{TSH}$ as a predictive factor was confirmed in studies assessing radioiodine ablation failure and the need for re-ablation in low- and intermediate-risk groups of patients ${ }^{48,61}$. For example, one study evaluated 740 such patients, with the $\mathrm{Tg} / \mathrm{TSH}$ ratio determined to be a more powerful prognostic factor than $\mathrm{Tg}$ alone, and higher $\mathrm{Tg} / \mathrm{TSH}$ ratios were found to be an independent predictor of treatment failure in a multivariate logistic regression analysis. Patients with $\mathrm{Tg} / \mathrm{TSH}>0.126$ had a higher probability of radioiodine ablation failure ${ }^{48}$.

In another study, which compared $\mathrm{Tg}$ and $\mathrm{Tg} / \mathrm{TSH}$ ratio, also in low and intermediate groups of patients, and re-ablation outcomes, TSH significantly increased, $\mathrm{Tg}$ decreased, and $\mathrm{Tg} / \mathrm{TSH}$ ratio decreased from $0.115 \pm 0.217$ to $0.034 \pm 0.071$ prior to re-ablation. A positive association was observed between treatment failure and $\operatorname{Tg} 2$ levels, as well as between treatment failure and $\mathrm{Tg} 2 / \mathrm{TSH} 2$ ratio $^{61}$. In a study by Lin et al., the $\mathrm{Tg} / \mathrm{TSH}$ ratio was considered as a predictive factor for treatment failure in patients with $\mathrm{DTC}^{62}$. Further studies are needed to evaluate the predictive and prognostic value of this easy calculable variable in patients undergoing TSH stimulation.

\section{Value of Thyroglobulin in Dynamic Risk Stratification}

The 2015 ATA guidelines have classified patients with DTC into low-, intermediate- and high-risk groups ${ }^{11}$. The risk of recurrence is associated with risk stratification, with the risk of recurrence in the ATA intermediate-risk group ranging from 3\% to 9\%, while the risk of recurrence in ATA high-risk patients ranges from $23 \%$ to $40 \%$. However, the initially estimated recurrence risk should be continually modified during follow up, since it can change over time as a function of disease status and response to therapy ${ }^{11,63}$. The majority of DTC patients show elevated preoperative $\mathrm{Tg}$, but the predictive role has not been clearly outlined, since immunoassays cannot differentiate between $\mathrm{Tg}$ secreted by normal tissue and by malignant thyroid cancer cells ${ }^{64}$.

All patients with high-risk according to ATA should receive I-131 treatment, as this therapy improves both disease-free and disease-specific survival. In ATA low-risk patients with tumor size $\leq 1 \mathrm{~cm}$, there is no indication for postoperative I-131 ablation therapy. However, in low-risk group patients with other risk factors, as well as in ATA intermediate-risk patients data regarding indications for I-131 ablation are conflicting, and therefore I-131 ablation therapy is selectively utilized ${ }^{11}$. The response to initial therapy (with four categories of treatment response) was introduced by Tuttle et al. and modified in another study by Vaisman et al. ${ }^{65,66}$. Thyroglobulin measurement is one of the main factors in "response to therapy reclassification" in patients receiving radioiodine remnant ablation after total thyroidectomy ${ }^{11}$.

Patients with suppressed $\mathrm{Tg}<0.2 \mathrm{ng} / \mathrm{mL}$, TSH stimulated $\mathrm{Tg}<1 \mathrm{ng} / \mathrm{mL}$, and with negative imaging studies fall into the excellent response to therapy subgroup, with a very low risk of recurrence, and almost no disease-specific mortality ${ }^{65,67-69}$. The "biochemical incomplete response" category includes patients with negative imaging studies, but with elevated $\mathrm{Tg}$ levels following treatment (suppressed $\mathrm{Tg} \geq 1 \mathrm{ng} / \mathrm{mL}$ or stimulated $\mathrm{Tg} \geq 10 \mathrm{ng} / \mathrm{mL}$ ), or with rising $\mathrm{TgAb}$ values. The mortality rate in this subgroup is minimal, but a significant number of patients in this group develop structural disease recurrence ${ }^{65,70}$.

In the group with functional or structural evidence of disease (structural incomplete response), the $\mathrm{Tg}$ level and the presence (or absence) of $\mathrm{TgAb}$ do not change the response classification of these patients. The indeterminate response group includes patients with biochemical or structural findings that cannot be classified as either benign or malignant. Patients with non-stimulated detectable levels $(\mathrm{Tg}<1 \mathrm{ng} / \mathrm{mL})$, or stimulated $\mathrm{Tg}$ detectable levels $(\mathrm{Tg}<10 \mathrm{ng} / \mathrm{mL})$ fall into this subgroup. The patients with stable or declining anti-Tg antibodies without structural or functional disease are part of this "response" group ${ }^{65,70}$.

\section{Thyroglobulin in Long-Term Follow-up of Patients with Differentiated Thyroid Cancer}

Long-term monitoring of patients with DTC is guided by the patient's response to therapy during the 
first year of follow-up. Most cases with recurrences of DTC occur during the first years of follow-up, but may occasionally also occur many years after initial treatment ${ }^{71}$. At each follow-up, clinicians reclassify ongoing management recommendations in accordance with the patient's current clinical status. Detection of the possible persistent or recurrent disease during the first year after thyroidectomy is obtained with neck ultrasonography and measurement of TSH, as well as serum Tg levels. Additional imaging such as MRI, $\mathrm{CT}^{72}$, and FDG-PET-CT ${ }^{73}$ is usually reserved for high-risk patients who typically have either biochemical or structural incomplete response to initial therapy and follow-up of intermediate-risk patients who demonstrate structural or biochemical incomplete response to treatment during the first year of follow-up. Diagnostic I-131 whole body scintigraphy has a role in the follow-up of these patients with high or intermediate risk of disease, but not in the follow-up of low-risk patients.

Serum $\mathrm{Tg}$ and $\mathrm{TgAb}$ in patients on thyroid hormone suppression are generally measured every 3 to 6 months for the first year following initial treatment. The interpretation of serum $\mathrm{Tg}$ depends on the type of initial therapy. For patients with total thyroidectomy and radioiodine remnant ablation, non-stimulated $\mathrm{Tg}$ should be $<0.2 \mathrm{ng} / \mathrm{mL}$ and stimulated $\mathrm{Tg}<1 \mathrm{ng} / \mathrm{mL}$ in the absence of interfering antibodies. In patients with lobectomy, serum $\mathrm{Tg}$ levels are less useful because they will not reflect the presence or absence of malignant tissue, but will depend on the remaining thyroid lobe volume, current iodine status and TSH concentration. In these patients, follow-up is performed by neck ultrasonography and, when necessary, US-guided fine needle aspiration (FNA) of any suspected metastatic foci ${ }^{24}$.

Neck US is performed at 6- to 12-month intervals depending on the patient's risk stratification. Cervical lymph nodes are the most common site of recurrence in patients with papillary carcinoma. The most sensitive technique for localization of recurrent tumor in the neck is US. Metastatic lymph nodes on US demonstrate a cystic appearance, microcalcifications, bulging shape, loss of normal hilum, and peripheral vascularization ${ }^{19,74}$. US-guided FNA of suspected lymph nodes with $\mathrm{Tg}$ measurement in aspirates (FNA-Tg) should be performed in patients with suspected nodal metastases $^{19}$. Values under $1 \mathrm{ng} / \mathrm{mL}$ are considered normal, values of $1-10 \mathrm{ng} / \mathrm{mL}$ should be compared with the results of cytology, and values above $10 \mathrm{ng} /$ $\mathrm{mL}$ suggest the presence of malignancy ${ }^{19}$. Some authors suggest comparison of FNA-Tg and serum $\mathrm{Tg}$ levels as worthwhile. FNA-Tg is highly reliable in the diagnosis of neck nodal metastases ${ }^{75}$.

Serum Tg may fail to identify patients with a relatively small volume of metastatic disease. These small metastases are often located in the neck region and US is the method of choice for detection of nodal disease in these patients ${ }^{11}$. In cases with elevated serum $\mathrm{Tg}$ levels and negative radioiodine scan, the explanation for such findings could be the presence of tumor deposits too small to be detected by a scintillation camera, or loss of iodine uptake through tumor de-differentiation $^{76}$. In such patients, neck ultrasound and neck/chest CT may be performed in order to detect metastatic disease. If negative, other imaging methods should be performed. In high-risk patients and in those with serum $\mathrm{Tg}>10 \mathrm{ng} / \mathrm{mL},[18 \mathrm{~F}]-\mathrm{FGD}$ PET/ CT should also be performed ${ }^{73,77}$.

\section{Thyroglobulin Doubling Time}

In medullary thyroid cancer, measurements of serum calcitonin and carcinoembryonic antigen (CEA) doubling-times have prognostic implications ${ }^{78,79}$. Miyauchi et al. have described the prognostic impact of serum $\mathrm{Tg}$ doubling time (Tg-DT) during follow up and under thyrotropin suppression. In this study, patients were divided into several groups: Tg-DT $<1$ year, $1-3$ years, and $\geq 3$ years. In the group with a TgDT of $<1$ year, disease-specific survival at 10 years was $50 \%$, in the group with Tg-DT of 1-3 years it was $95 \%$, and in other groups disease-specific survival was 100\%. Thyroglobulin DT was found to be a statistically significant indicator of survival by univariate analysis. Multivariate analysis also revealed Tg-DT to be an independent predictor of distant metastases and loco-regional treatment failure ${ }^{80}$.

Several studies addressed the issue of advanced/recurrent thyroid cancer and Tg-DT values. In a study by Rossling et al., the Tg-DT and other prognostic markers in patients with recurrent/progressive DTC were evaluated in uni- and multivariate analysis. The median observed Tg-DT was 212 days. Mortality risk was two times higher in patients with $\mathrm{Tg}-\mathrm{DT}<5$ months as compared with patients with $\mathrm{Tg}-\mathrm{DT}>14$ 
months ${ }^{81}$. In a study by Giovanella et al., the predictive value of Tg and $\mathrm{Tg}$-DT on positive [18F]-FDG PET/ CT scan in patients with biochemical recurrence of DTC was assessed. Serum Tg levels were higher in patients with positive [18F]-FDG PET/CT scan as compared to patients with negative PET/CT, and the authors concluded that the accuracy of $[18 \mathrm{~F}]-\mathrm{FDG}$ $\mathrm{PET} / \mathrm{CT}$ significantly improved with serum $\mathrm{Tg}$ levels $>5.5 \mathrm{ng} / \mathrm{mL}$ during levothyroxine treatment, or with Tg-DT $<1$ year $^{82}$.

\section{References}

1. Pacini F, Castagna MG, Brilli L, Pentheroudakis G, on behalf of the ESMO Guidelines Working Group. Thyroid cancer: ESMO Clinical practice guidelines for diagnosis, treatment and follow-up. Ann Oncol. 2012;23 (Suppl 7):vii110-vii119.

2. Aschebrook-Kilfoy B, Ward MH, Sabra MM, Devesa SS. Thyroid cancer incidence patterns in the United States by histologic type, 1996-2006. Thyroid. 2014;21:125-34. http://dx.doi. org/10.1089/thy.2010.0021

3. Croatian Institute for Public Health. Croatian National Cancer Registry. Cancer incidence in Croatia 2014. Bulletin No.29, Zagreb, 2016.

4. Davies L, Welch HG. Current thyroid cancer trends in the United States. JAMA Otolaryngol Head Neck Surg. 2014; 140:317-22. http://dx.doi.org/10.1001/jamaoto.2014.1

5. Li N, Du XL, Reitzel LR, Xu L, Sturgis EM. Impact of enhanced detection on the increase in thyroid cancer incidence in the United States: review of incidence trends by socioeconomic status within the surveillance, epidemiology, and end results registry, 1980-2008. Thyroid. 2013;23:103-10. http://dx.doi. org/10.1089/thy.2012.0392

6. Staničić J, Prpić M, Jukić T, Borić M, Kusić Z. Thyroid nodularity - true epidemic or improved diagnostics. Acta Clin Croat. 2009; 48:413-8.

7. Pacini F, Schlumberger M, Dralle H, Elisei R, Smith JW, Wiersinga W, and European Thyroid Cancer Taskforce. European consensus for the management of patients with differentiated thyroid carcinoma of the follicular epithelium. Eur J Endocrinol. 2006;154:787-803. http://dx.doi.org/10.1530/eje.1.02158

8. Kwon H, Jeon MJ, Kim WG, Park S, Kim M, Song DE, et al. A comparison of lobectomy and total thyroidectomy in patients with papillary thyroid microcarcinoma: a retrospective individual risk factor-matched cohort study. Eur J Endocrinol. 2017;176:371-8. http://dx.doi.org/10.1530/EJE-16-0845

9. Castagna MG, Cevenini G, Theodoropoulou A, Maino F, Memmo S, Claudia C, et al. Post-surgical thyroid ablation with low or high radioiodine activities results in similar outcomes in intermediate risk differentiated thyroid cancer patients. Eur J Endocrinol. 2013;169:23-9. http://dx.doi.org/10.1530/EJE-12-0954
10. Reiners C, Hanscheid H, Luster M, Lassman M, Verbung FA. Radioiodine for remnant ablation and therapy of metastatic disease. Nat Rev Endocrinol. 2011;7:589-95. http://dx.doi. org/10.1038/nrendo.2011.134

11. Haugen BR, Alexander EK, Bible KC, Doherty GM, Mandel SJ, Nikiforov YE, et al. 2015 American Thyroid Association Management Guidelines for Adult Patients with Thyroid Nodules and Differentiated Thyroid Cancer: The American Thyroid Association Guidelines Task Force on Thyroid Nodules and Differentiated Thyroid Cancer. Thyroid. 2016;26:1-133. http:// dx.doi.org/10.1089/thy.2015.0020

12. Diesel S, Holzberger B, Mader U,Grelle I, Smit JW, Buck AK, et al. Impact of moderate vs. stringent TSH suppression on survival in advanced differentiated thyroid carcinoma. Clin Endocrinol (Oxf). 2012;76:586-92.

http://dx.doi.org/10.1111/j.1365-2265.2011.04272.x

13. Verburg FA, Mader U, Tanase K, Thies ED, Diessl S, Buck AK, et al. Life expectancy is reduced in differentiated thyroid cancer patients $\geq 45$ years old with extensive local tumour invasion, lateral lymph node, or distant metastases at diagnosis and normal in all other DTC patients. J Clin Endocrinol Metab. 2013;98:172-80. http://dx.doi.org/10.1210/jc.2012-2458

14. Malthiéry Y, Lissitzky S. Primary structure of human thyroglobulin deduced from the sequence of its 8448-base complementary DNA. Eur J Biochem. 1987;165:491-8.

15. Jukić T,Zimmermann MB, Granić R, Prpić M, Krilić D, Jureša $\mathrm{V}$, et al. Sufficient iodine intake in schoolchildren from Zagreb - assessment with dried blood spot thyroglobulin as a new functional biomarker for iodine deficiency. Acta Clin Croat. 2015;54:424-31.

16. Schlumberger M. Medical progress: papillary and follicular thyroid carcinoma. N Engl J Med. 1998;338:297-306.

17. Franceschi M, Kusić Z, Franceschi D, Lukinac Lj, Rončević $S$. Thyroglobulin determination, neck ultrasonography and iodine-131 whole body scintigraphy in differentiated thyroid cancer. J Nucl Med. 1996;37:446-51.

18. Kusić Z, Jukić T, Dabelić N, Franceschi M; Hrvatsko društvo za štitnjaču. [Croatian Thyroid Society guidelines for the management of patients with differentiated thyroid cancer]. Lijec Vjesn. 2008;130:213-27. (in Croatian)

19. Leenhardt L, Erdogan MF, Hegedus L,Mandel SJ, Paschke R, Rago T, et al. 2013 European Thyroid Association Guidelines for Cervical Ultrasound Scan and Ultrasound-Guided Techniques in the Postoperative Management of Patients with Thyroid Cancer. Eur Thyroid J. 2013;2:147-59.http://dx.doi. org/10.1159/000354537

20. Shamim SE, Nang LB, Shuaib IL, Muhamad NA. Clinical determinants of fluorodeoxyglucose positron emission tomography/computed tomography in differentiated thyroid cancer patients with elevated thyroglobulin and negative (131) iodine whole body scans after (131) iodine therapy. Malays J Med Sci. 2014;21:38-46.

21. Pak K, Kim SJ, Kim IJ, Kim BH, Kim SS, Jeon YK. The role of $18 \mathrm{~F}$-fluorodeoxyglucose positron emission tomography in dif- 
ferentiated thyroid cancer before surgery. Endocr Relat Cancer. 2013;20:R203-13. http://dx.doi.org/10.1530/ERC-13-0088

22. Johnson NA, Tublin ME. Postoperative surveillance of differentiated thyroid carcinoma: rationale, techniques, and controversies. Radiology. 2008;249:429-44.

http://dx.doi.org/ 10.1148/radiol.2492071313

23. Grebe SKG. Diagnosis and management of thyroid carcinoma: a focus on serum thyroglobulin. Expert Rev Endocrinol Metab. 2009;4:25-43.

24. Giovanella L, Clark MP, Chiovato L, Duntas L, Elisei R, Feldt-Rasmussen U, et al. Thyroglobulin measurement using highly sensitive assays in patients with differentiated thyroid cancer: a clinical position paper. Eur J Endocrinol. 2014; 171:R33-R46. http://dx.doi.org/10.1530/EJE-14-0148

25. Caturegli P, Kuppers RC, Mariotti S, Burek CL, Pinchera A, Ladenson PW, et al. IgG subclass distribution of thyroglobulin antibodies in patients with thyroid disease. Clin Exp Immunol. 1994;98:464-9.

26. Spencer CA, LoPresti JS, Fatemi S, Nicoloff JT. Detection of residual and recurrent differentiated thyroid carcinoma by serum thyroglobulin measurement. Thyroid. 1999;9:435-41.

27. Spencer CA. Challenges of serum thyroglobulin ( $\mathrm{Tg})$ measurement in the presence of $\mathrm{Tg}$ autoantibodies. J Clin Endocrinol Metab. 2004;89:3702-4.

28. Spencer C, Fatemi S. Thyroglobulin antibody (TgAb) methods - strengths, pitfalls and clinical utility for monitoring $\mathrm{Tg} \mathrm{Ab}-$ positive patients with differentiated thyroid cancer. Best Pract Res Clin Endocrinol Metab. 2013;27:701-12. http://dx.doi. org/10.1016/j.beem.2013.07.003

29. Gorges R, Maniecki M, Jentzen W, Sheu SN, Mann K, Bockisch A, et al. Development and clinical impact of thyroglobulin antibodies in patients with differentiated thyroid carcinoma during the first 3 years after thyroidectomy. Eur J Endocrinol. 2005;153:49-55.

30. Seo JH, Lee SW, Ahn BC, Lee J. Recurrence detection in differentiated thyroid cancer patients with elevated serum level of antithyroglobulin antibody: special emphasis on using (18) F-FDG PET/CT. Clin Endocrinol (Oxf). 2010;72:558-63. http://dx.doi.org/10.1111/j.1365-2265.2009.03693.x

31. Kim WG, Yoon JH, Kim WB, Kim TY, Kim EY, Kim JM, et al. Change of serum antithyroglobulin antibody levels is useful for prediction of clinical recurrence in thyroglobulin negative patients with differentiated thyroid carcinoma. J Clin Endocrinol Metab. 2008;93:4683-9.

http://dx.doi.org/10.1210/jc.2008-0962

32. Rinaldi S, Plummer M, Biessy C, Tsilidis KK, Østergaard JN, Overvad K, et al. Thyroid-stimulating hormone, thyroglobulin, and thyroid hormones and risk of differentiated thyroid carcinoma: the EPIC study. J Natl Cancer Inst. 2014;106:dju097. http://dx.doi.org/10.1093/jnci/dju097

33. Giovanella L, Ceriani L, Maffioli M. Postsurgery serum thyroglobulin disappearance kinetics in patients with differentiated thyroid carcinoma. Head Neck. 2010;32:568-71. http://dx.doi. org/10.1002/hed.21214.
34. Hocevar M, Auersperg M, Stanovnik L. The dynamics of serum thyroglobulin elimination from the body after thyroid surgery. Eur J Surg Oncol. 1997;23:208-10.

35. Giovanella L, Treglia G, Sadeghi R, Trimboli P, Ceriani L, Verburg FA. Unstimulated high-sensitive thyroglobulin in follow-up of differentiated thyroid cancer patients: a metaanalysis. J Clin Endocrinol Metab. 2014;99:440-7. http://dx.doi.org/10.1210/jc.2013-3156

36. Kloos RT. Thyroid cancer recurrence in patients clinically free of disease with undetectable or very low serum thyroglobulin values. J Clin Endocrinol Metab. 2010;95:5241-8. http://dx.doi.org/10.1210/jc.2010-1500

37. Mallick U, Harmer C, Yap B, Wadsley J, Clarke S, Moss L, et al. Ablation with low-dose radioiodine and thyrotropin alfa in thyroid cancer. N Engl J Med. 2012;366:1674-85. http://dx.doi.org/10.1056/NEJMoa1109589

38. Schlumberger M, Catargi B, Borget I, Deandreis D, Zerdoud S, Bridji B, et al. Strategies of radioiodine ablation in patients with low-risk thyroid cancer. N Engl J Med. 2012;366:1663-73. http://dx.doi.org/10.1056/NEJMoa1108586.

39. Giovanella L, Piccardo A. A "new/old method" for TSH stimulation: could a third way to prepare DTC patients for (131) I remnant ablation possibly exist? Eur J Nucl Med Mol Imaging. 2016;43:221-3. http://dx.doi.org/10.1007/s00259-015-3245-9

40. Robbins RJ, Driedger A, Magner J. Recombinant human thyrotropin-assisted radioiodine therapy for patients with metastatic thyroid cancer who could not elevate endogenous thyrotropin or be withdrawn from thyroxine. Thyroid. 2006;16: 1121-30. http://dx.doi.org/10.1089/thy.2006.16.1121

41. Kowalska A, Pałyga I, Gąsior-Perczak D, Walczyk A, Trybek T, Sluszniak A, et al. The cut-off level of recombinant human TSH-stimulated thyroglobulin in the follow-up of patients with differentiated thyroid cancer. PLoS One. 2015;31(10): e0133852. http://dx.doi.org/10.1371/journal.pone.0133852.

42. Edmonds CJ, Hayes S, Kermode JC, Thompson BD. Measurement of serum TSH and thyroid hormones in the management of treatment of thyroid carcinoma with radioiodine. $\mathrm{Br} \mathrm{J} \mathrm{Ra-}$ diol. 1977;50:799-807.

43. Torres MS, Ramirez L, Simkin PH, Braverman LE, Emerson $\mathrm{CH}$. Effect of various doses of recombinant human thyrotropin on the thyroid radioactive iodine uptake and serum levels of thyroid hormones and thyroglobulin in normal subjects. J Clin Endocrinol Metab. 2001;86:1660-4. http://dx.doi.org/10.1210/jcem.86.4.7405

44. Vrachimis A, Riemann B, Mäder U, Reiners C, Verburg FA. Endogenous TSH levels at the time of (131) I ablation do not influence ablation success, recurrence-free survival or differentiated thyroid cancer-related mortality. Eur J Nucl Med Mol Imaging. 2016;43:224- 31. http://dx.doi.org/10.1007/ s00259-015-3223-2

45. Zhao T, Liang J, Guo Z, Li T, Lin Y. In patients with low- to intermediate-risk thyroid cancer, a preablative thyrotropin level of $30 \mu \mathrm{IU} / \mathrm{mL}$ is not adequate to achieve better response to 131I therapy. Clin Nucl Med. 2016;41:454-8. http://dx.doi.org/ 10.1097/RLU.0000000000001167 
46. Lawal IO, Nyakale NE, Harry LM, Lengana T, Mokgoro NP, Vorster M, et al. Higher preablative serum thyroid-stimulating hormone level predicts radioiodine ablation effectiveness in patients with differentiated thyroid carcinoma. Nucl Med Commun. 2017;38:222-7. http://dx.doi.org/10.1097/MNM.0000000000000640

47. Prpic M, Dabelic N, Stanicic J, Jukic T, Milosevic M, Kusic Z. Adjuvant thyroid remnant ablation in patients with differentiated thyroid carcinoma confined to the thyroid: a comparison of ablation success with different activities of radioiodine (I-131). Ann Nucl Med. 2012;26:744-51. http://dx.doi.org/10.1007/s12149-012-0637-9

48. Prpic M, Kust D, Kruljac I, Kirigin LS, Jukic T, Dabelic N, et al. Prediction of radioactive iodine remnant ablation failure in patients with differentiated thyroid cancer: a cohort study of 740 patients. Head Neck. 2017;39:109-15. http://dx.doi.org/ 10.1002/hed.24550

49. Pelttari H, Valimaki MJ, Loyttyniemi E, Schalin-Jantti C. Post-ablative serum thyroglobulin is an independent predictor of recurrence in low-risk differentiated thyroid carcinoma: a 16-year follow-up study. Eur J Endocrinol. 2010;163:757-63. http://dx.doi.org/ 10.1530/EJE-10-0553

50. Giovanella L, Ceriani L, Ghelfo A, Keller F. Thyroglobulin assay 4 weeks after thyroidectomy predicts outcome in low-risk papillary thyroid carcinoma. Clin Chem Lab Med. 2005;43: 843-7. http://dx.doi.org/10.1515/CCLM.2005.142

51. Piccardo A, Arecco F, Puntoni M, Foppiani L, Cabria M, Corvisieri $\mathrm{S}$, et al. Focus on high-risk DTC patients: high postoperative serum thyroglobulin level is a strong predictor of disease persistence and is associated to progression-free survival and overall survival. Clin Nucl Med. 2013;38:18-24. http://dx.doi.org/10.1097/RLU.0b013e318266d4d8

52. Heemstra KA, Liu YY, Stokkel M, Kievit J, Corssmit E, Pereira $\mathrm{AM}$, et al. Serum thyroglobulin concentrations predict diseasefree remission and death in differentiated thyroid carcinoma. Clin Endocrinol (Oxf). 2007;66:58-64. http://dx.doi.org/10.1111/j.1365-2265.2006.02685.x

53. Kim TY, Kim WB, Kim ES, Ryu JS, Yeo JS, Kim SC, et al. Serum thyroglobulin levels at the time of 131I remnant ablation just after thyroidectomy are useful for early prediction of clinical recurrence in low-risk patients with differentiated thyroid carcinoma. J Clin Endocrinol Metab. 2005;90:1440-5. http:// dx.doi.org/10.1210/jc.2004-1771

54. Rosario PW, Xavier AC, Calsolari MR. Value of postoperative thyroglobulin and ultrasonography for the indication of ablation and 131I activity in patients with thyroid cancer and low risk of recurrence. Thyroid. 2011;21:49-53.

http://dx.doi.org/10.1089/thy.2010.0145

55. Nascimento C, Borget I, al Ghuzlan A, Deandreis D, Chami L, Travagli JP, et al. Persistent disease and recurrence in differentiated thyroid cancer patients with undetectable postoperative stimulated thyroglobulin level. Endocr Relat Cancer. 2011;18: R29-R40. http://dx.doi.org/10.1677/ERC-10-0292
56. Orlov S, Salari F, Kashat L, Freeman JL, Vescan A, Witterick IJ, et al. Postoperative stimulated thyroglobulin and neck ultrasound as personalized criteria for risk stratification and radioactive iodine selection in low- and intermediate-risk papillary thyroid cancer. Endocrine. 2015;50:130-7.

http://dx.doi.org/10.1007/s12020-015-0575-0

57. Mourão GF, Rosario PW, Calsolari MR. Low postoperative nonstimulated thyroglobulin as a criterion to spare radioiodine ablation. Endocr Relat Cancer. 2016;23:47-52.

http://dx.doi.org/10.1530/ERC-15-0458

58. Tamilia M, Al-Kahtani N, Rochon L, Hier MP, Payne RJ, Holcroft CA, et al. Serum thyroglobulin predicts thyroid remnant ablation failure with $30 \mathrm{mCi}$ iodine- 131 treatment in $\mathrm{pa}^{-}$ tients with papillary thyroid carcinoma. Nucl Med Commun. 2011;32:212-20.

http://dx.doi.org/10.1097/MNM.0b013e328341c802

59. Bernier MO, Morel O, Rodien P, Muratet JP, Giraud P, Rohmer $\mathrm{V}$, et al. Prognostic value of an increase in the serum thyroglobulin level at the time of the first ablative radioiodine treatment in patients with differentiated thyroid cancer. Eur J Nucl Med Mol Imaging. 2005;32:1418-21.

http://dx.doi.org/10.1007/s00259-005-1866-0

60. Trevizam PG, Tagliarini JV, Castilho EC, de Alencar Marques M, Kiy Y, da Silva Mazeto GM. Thyroglobulin levels and thyroglobulin/thyrotropin ratio could predict the success of the ablative/therapeutic $131 \mathrm{I}$ in the differentiated thyroid cancers. Endocr Res. 2017;42:42-8.

http://dx.doi.org/10.3109/07435800.2016.1173056

61. Prpic M, Kruljac I, Kust D, Kirigin LS, Jukic T, Dabelic N, et al. Re-ablation I-131 activity does not predict treatment success in low- and intermediate-risk patients with differentiated thyroid carcinoma. Endocrine. 2016;52:602-8.

http://dx.doi.org/10.1007/s12020-015-0846-9

62. Lin Y, Li T, Liang J, Li X, Qiu L, Wang S, et al. Predictive value of preablation stimulated thyroglobulin and thyroglobulin/thyroid-stimulating hormone ratio in differentiated thyroid cancer. Clin Nucl Med. 2011;36:1102-5. http://dx.doi.org/ 10.1097/RLU.0b013e3182291c65

63. Riemann B, Kramer JA, Schmid KW, Dralle H, Dietlein M, Schicha $\mathrm{H}$, et al. Risk stratification of patients with locally aggressive differentiated thyroid cancer. Results of the MSDS trial. Nuklearmedizin. 2010;49:79-84.

http://dx.doi.org/10.3413/nukmed-0302

64. Giovanella L. False-negative thyroglobulin measurement in recurrent/metastatic thyroid carcinomas. Eur J Nucl Med Mol Imaging. 2009;36:326-7. http://dx.doi.org/10.1007/s00259-008-1005-9

65. Tuttle RM, Tala H, Shah J, Leboeuf R, Ghossein R, Gonen M, et al. Estimating risk of recurrence in differentiated thyroid cancer after total thyroidectomy and radioactive iodine remnant ablation: using response to therapy variables to modify the initial risk estimates predicted by the new American Thyroid Association staging system. Thyroid. 2010;20:1341-9. http:// dx.doi.org/10.1089/thy.2010.0178 
66. Vaisman F, Shaha A, Fish S, Michael TR. Initial therapy with either thyroid lobectomy or total thyroidectomy without radioactive iodine remnant ablation is associated with very low rates of structural disease recurrence in properly selected patients with differentiated thyroid cancer. Clin Endocrinol (Oxf). 2011;75:112-9.

http://dx.doi.org/ 10.1111/j.1365-2265.2011.04002.x

67. Castagna MG, Maino F, Cipri C, Belardini V, Theodoropoulou A, Cevenini G, et al. Delayed risk stratification, to include the response to initial treatment (surgery and radioiodine ablation), has better outcome predictivity in differentiated thyroid cancer patients. Eur J Endocrinol. 2011;165:441-6.

http://dx.doi.org/10.1530/EJE-11-0466

68. Piccardo A, Arecco F, Morbelli S, Bianchi P, Barbera F, Finessi $\mathrm{M}$, et al. Low thyroglobulin concentrations after thyroidectomy increase the prognostic value of undetectable thyroglobulin levels on levo-thyroxine suppressive treatment in low-risk differentiated thyroid cancer. J Endocrinol Invest. 2010;33:83-7. http://dx.doi.org/10.3275/6471

69. Brassard M, Borget I, Edet-Sanson A, Giraudet AL, Mundler O, Toubeau M, et al. Long-term follow-up of patients with papillary and follicular thyroid cancer: a prospective study on 715 patients. J Clin Endocrinol Metab. 2011;96:1352-9. http://dx.doi.org/10.1210/jc.2010-2708

70. Vaisman F, Momesso D, Bulzico DA, Pessoa CH, Dias F, Corbo $\mathrm{R}$, et al. Spontaneous remission in thyroid cancer patients after biochemical incomplete response to initial therapy. Clin Endocrinol (Oxf). 2012;77:132-8. http://dx.doi.org/10.1111/j.1365-2265.2012.04342.x

71. Shaha AR, Loree TR, Shah JP. Prognostic factors and risk group analysis in follicular carcinoma of the thyroid. Surgery. 1995;118:1131-6.

72. Gagel RF, Goepfert H, Callender DL. Changing concepts in pathogenesis and management of thyroid carcinoma. CA Cancer J Clin. 1996;46:261-83.

73. Robbins RJ, Wan Q, Grewal RK, Reibke R, Gonen M, Strauss $\mathrm{HW}$, et al. Real-time prognosis for metastatic thyroid carcinoma based on 2-[18F]fluoro-2-deoxy-D-glucose-positron emission tomography scanning. J Clin Endocrinol Metab. 2006;91: 498-505.

74. Leboulleux S, Girard E, Rose M, Travagli JP, Sabbah N, Caillou $\mathrm{B}$, et al. Ultrasound criteria of malignancy for cervical lymph nodes in patients followed up for differentiated thyroid cancer. J Clin Endocrinol Metab. 2007;92:3590-4.

http://dx.doi.org/10.1210/jc.2007-0444

75. Grani G, Fumarola A. Thyroglobulin in lymph node fine-needle aspiration wash-out: a systematic review and meta-analysis of diagnostic accuracy. J Clin Endocrinol Metab. 2014;99: 1970-82. http://dx.doi.org/10.1210/jc.2014-1098

76. Fatourechi V, Hay ID. Treating the patient with differentiated thyroid cancer with thyroglobulin-positive iodine-131 diagnostic scan-negative metastases: including comments on the role of serum thyroglobulin monitoring in tumor surveillance. Semin Nucl Med. 2000;30:107-14.

77. Leboulleux S, Schroeder PR, Schlumberger M, Ladenson PW. The role of PET in follow-up of patients treated for differentiated epithelial thyroid cancers. Nat Clin Pract Endocrinol Metab. 2007;3:112-21. http://dx.doi.org/10.1038/ncpendmet0402

78. Barbet J, Campion L, Kraeber-Bodéré F, Chatal JF; GTE Study Group. Prognostic impact of serum calcitonin and carcinoembryonic antigen doubling-times in patients with medullary thyroid carcinoma. J Clin Endocrinol Metab. 2005;90: 6077-84. http://dx.doi.org/10.1210/jc.2005-0044

79. Laure Giraudet A, Al Ghulzan A, Auperin A, Leboulleux S, Chehboun A, Troalen F, et al. Progression of medullary thyroid carcinoma: assessment with calcitonin and carcinoembryonic antigen doubling times. Eur J Endocrinol. 2008;158:239-46. http://dx.doi.org/10.1530/EJE-07-0667

80. Miyauchi A, Kudo T, Miya A, Kobayashi K, Ito Y, Takamura Y, et al. Prognostic impact of serum thyroglobulin doubling-time under thyrotropin suppression in patients with papillary thyroid carcinoma who underwent total thyroidectomy. Thyroid. 2011;21:707-16. http://dx.doi.org/10.1089/thy.2010.0355

81. Rössing RM, Jentzen W, Nagarajah J, Bockisch A, Görges R. Serum thyroglobulin doubling time in progressive thyroid cancer. Thyroid. 2016;26:1712-8. http://dx.doi.org/10.1089/thy.2016.0031

82. Giovanella L, Trimboli P, Verburg FA, Treglia G, Piccardo A, Foppiani L, et al. Thyroglobulin levels and thyroglobulin doubling time independently predict a positive 18F-FDG PET/ CT scan in patients with biochemical recurrence of differentiated thyroid carcinoma. Eur J Nucl Med Mol Imaging. 2013; 40:874-80. http://dx.doi.org/10.1007/s00259-013-2370-6 


\section{Sažetak \\ TIREOGLOBULIN: TUMORSKI BILJEG DIFERENCIRANIH KARCINOMA ŠTITNJAČE - KLINIČKA RAZMATRANJA}

\section{Prpić, M. Francescbi, M. Romić, T. Jukić i Z. Kusić}

Početno liječenje većine bolesnika s diferenciranim karcinomom štitnjače uključuje kirurško odstranjenje štitnjače. Poslijeoperacijsko liječenje radioaktivnim jodom (I-131) indicirano je u većine visokorizičnih bolesnika, dok je primjena I-131 u bolesnika niskog i srednjeg rizika predmet rasprave. U prethodnih nekoliko desetljeća tireoglobulin $(\mathrm{Tg})$ je prihvaćen kao primarni biokemijski tumorski biljeg visoke osjetljivosti i specifičnosti u bolesnika s diferenciranim karcinomom štitnjače. Mjerenje Tg može se izvoditi tijekom uzimanja hormonske terapije L-tiroksinom ili uz stimulaciju tireotropinom (TSH). Stimulacija putem TSH može se postići prekidom hormonske terapije L-tiroksinom ili uz primjenu rekombinantnog humanog TSH (rhTSH). Dugi niz godina se granična vrijednost TSH $\geq 30 \mathrm{mIU} / \mathrm{L}$ smatrala zadovoljavajućom za stimulaciju Tg, međutim, novije spoznaje osporavaju tu granicu i zahtijevaju nova istraživanja i preporuke. Nedavno je uvedena podjela bolesnika u 4 rizične skupine ovisno o odgovoru na liječenje jodom-131 nakon totalne tireoidekotmije, a mjerenje Tg jedna je od glavnih odrednica podjele. U posljednje vrijeme se značenje pridaje omjeru Tg-TSH u predviđanju ishoda ablacije jodom-131, kao i prognostičko značenje vremena udvostručenja Tg. Poslijeoperacijska serumska vrijednost $\mathrm{Tg}$ je važan prognostički čimbenik i odrednica daljnjeg liječenja, a određivanje Tg je osnovna metoda dugoročnog praćenja bolesnika s diferenciranim karcinomom štitnjače.

Ključne riječi: Tireoglobulin; Tireoidni tumori; Tireoidektomija; Jod, radioizotopi; Tumorski biljezi, biološki; Tireoidni hormoni; Hrvatska 